
\title{
CIÊNCIA'NATURA
}

\section{Trends in the application of multimetric indexes in Brazil: scienciometric analyses related to fish fauna}

\author{
Douglas Ticiani, Raquel Fernanda Bogoni, Ana Cristina Algeri Eichelberger, Amanda Frigo Berlatto, \\ Gabriela Medeiros and Rosilene Luciana Delariva
}

Universidade Estadual do Oeste do Paraná - UNIOESTE, Cascavel-PR, Brasil.

\begin{abstract}
The evaluation of biotic integrity through multimetric analyses of the attributes of fish fauna is recognized as an important tool for water management and conservation policies. In this sense, the present study aimed to elucidate the most frequently used metrics in multimetric indexes (MMIs) on the basis on the fish assemblages in Brazil. An electronic search of the literature was carried out using indexing databases of periodicals. The criteria used for the selection of scientific articles were studies carried out in Brazilian territory and reports of the use of MMI with fish. A total of 32 publications were selected from 19 journals, 15 of which were Brazilian journals. The majority of the studies were carried out in streams (51.9\%), and there were no temporal patterns. The highest concentration of studies was observed in the southeast region. In all, 103 different metrics were used; those metrics highlighted attributes related to the trophic level, tolerance to hypoxia, and species composition. There was an increase over time of publications that reported on the use of specific metrics and environments, except for rivers. In comparison to other environments, the results of the metrics from streams were statistically different. Difficulties in terms of the applications of MMIs in Brazil are linked to the selection of aspects that characterize the condition of a habitat before the diagnosis of the ecological components in the classification of the environmental quality. Despite its importance, the lack of standardized metrics and the neglect of functional characteristics make it difficult to replicate the MMI.
\end{abstract}

Keywords: Biotic integrity. Ichthyofauna, Metrics. MMI. 


\section{Introdução}

The interferences of anthropogenic actions on natural systems generates impacts on biodiversity, whose intensity is generally proportional to the degree of environmental heterogeneity, the original characteristics of the environment, and the vulnerability of the involved species (BASTOS; ABILHOA, 2004; DIAS et al., 2016). In aquatic environments, this stress is reflected in different ways and at various levels of the ecosystems, such as at the level of the individual, the population, and the community (TUNDISI; TUNDISI, 2008).

Community-level investigations are considered to be adequate for the evaluation of ecological integrity (MARTINEZ-HARO et al., 2015), and the use of fish as biological indicators of environmental quality has gained support in recent decades (AZEVEDO et al., 2010; RUARO; GUBIANI, 2013). These organisms have specific responses to changes in habitat and toxic stressors, which is an indication of the biotic integrity of their environment. In addition, high physiological sensitivity in critical situations and participation in different trophic levels, reaching even the top e of trophic web (ARAÚJO, 1998; FLORES-LOPES; MALABARBA, 2007), are important characteristics for bioindication. Moreover, fish are widely distributed (reaching small and degraded waterways) and popularly known, presenting connection to society's appeals.

Based on the concept that the biotic integrity of an ecosystem is your capacity of maintainability, composition and functional organization of the communities (KARR; DUDLEY, 1981), Karr proposed the Index of Biotic Integrity (IBI) in 1981. It is a tool for to summarize the biological attributes or metrics that reflect anthropogenic disturbances capable of elucidating the environmental conditions of aquatic resources (KARR, 1981). It is considered to be the first description of a multimetric procedure that is based on the fish community (RUARO; GUABIANI, 2013). Initially applied to streams, the index received subsequent adaptations in several countries (LYONS et al., 2000; FISCH et al., 2016). The adaptations were used to assess diverse environments, which resulted in different nomenclatures to the multimetric indexes (MMI). For example, Jennings et al. (1995) considered the term "biotic integrity" inappropriate when adjusting the index for use with reservoirs because of the artificial nature of these sites. In addition, some adjustments have incorporated statistical criteria in the selection of the metrics (HERING et al., 2006), reference sites (WHITTIER et al., 2007), different scoring methods (BLOCKSOM, 2003), probabilistic sample design (HERLIHY et al., 2000), and correlation of metrics with environmental variation (CARVALHO et al., 2017).

The first MMI application study that used components of the fish fauna in Brazil was carried out by Araújo (1998) in the Paraíba do Sul River. The objective was to obtain a biological monitoring standard that allowed for inferences to be made about water quality. However, until 2008, of the 15 studies with this context in tropical regions, only three were carried out in Brazil (JARAMILLO-VILLA; CARAMASCHI, 2008). In a recent study, Dias et al. (2016) demonstrated that the application of the IBI did not stand out among the tendencies of the objectives in studies of ichthyofauna in Brazil. In addition, the focus of researchers seemed to be linked to the economic development of the government (AZEVEDO et al., 2010), which resulted in incipient databases and, consequently, restricted the application of indexes.

Since the 1970s, researchers and water resource managers in Western Europe and North America, for example, have been supported by government laws and agencies and have implemented the tool MMI in biomonitoring programs and environmental quality assessment (EUROPEAN COMMISSION, 2000; USEPA, 2002). In contrast, in Brazil, no mention is made about the use of biomonitoring to evaluate the quality of water in any of the legal provisions directed exclusively to water resources (BRASIL, 1934; 1997).

Given the potential response of Multimetric Indexes, since they integrate several components of the community, in comparison with specific descriptors (for example, indicator species), it becomes instigating to understand the dimensionality of use and gaps in the application of this tool in Brazil, showing the evolution of the frame after the Araújo's paper (1998) (in the last 20 years). On that basis, the present study has the following objectives: (i) to evaluate the temporal evolution of studies using MMIs and their geographic distribution, (ii) to list the environments where the indexes are most frequently applied; (iii) to identify patterns in the metrics used among the environments evaluated in Brazil, and (iv) to verify the similarity of the attributes used in different environments. In addition, the study also aims to identify knowledge gaps and contribute for future adaptations of the index, making it possible to broaden the discussions on the use of biological indicators for ecosystem assessment and monitoring.

\section{Materials and Methods}

The electronic search of the literature was carried out in 2016 and 2017 using the following databases: Thomson Reuters (ISI Web of Knowledge), SciELO, Scopus, Google Scholar, and CAPES Newspapers. Seven keywords were used-'Index of Biotic Integrity", "IBI", "multimetric indexes", "MMI", "fish", "fishes", and "Brazil"_ individually and simultaneously, in Portuguese and English. In order to find variations in terms, the asterisk $\left(^{*}\right)$ was added to the search after each keyword. The criteria used for the selection of the publications were studies that were carried out in the Brazilian territory and studies that used the fish community as an indicator of biotic integrity through the direct use of an MMI. Only papers of a scientific nature, published after the introduction of the theme in the national territory in 1998, were considered until year 2017. Studies 
published in local and non-indexed journals, as well as dissertations and theses, were not considered.

The selected articles were classified by the nationality of the journal, year of publication, watershed, and environments (that is, rivers, streams, reservoirs, and estuaries). The georeference mapping of the articles was done through the coordinates reported by the authors, with aid of the Quantum GIS Software, version 2.16.1 'Nødebo' (QGIS, 2016).

The metrics used to apply the calculation of the MMIs of each study were listed in this paper. Given the great similarity in the naming and representativeness of some metrics, the nominal grouping of metrics with equivalent characteristics was performed. The groupings were only used in the calculation of the relative frequencies in order to identify the most used metrics in the studies.

The rarefaction analysis, which is capable of comparing diversity in samples with different sizes, was used to identify qualitative and quantitative variations in the metrics used over time. The more upward the accumulation curve, the greater the probability of new metrics being employed in a given environment. In order to identify possible significant differences in the metrics used between the studied sites, the permutational one-factor analysis (PERMANOVA), based on the Jaccard distance (binary data), was used. The percentage similarity analysis (SIMPER) was used to determine which metrics were responsible for the differences. All of these analyses were performed using the Software Past 7.0 (HAMMER et al., 2001), and the significance level considered was $\alpha=0.05$.

\section{Results}

A total of 32 publications were selected from 19 journals, 15 of which were Brazilian journals (Supplementary 1). We did not observe a temporal pattern for the studies that used MMIs; however, there were two peaks of higher occurrence of publications with this objective (2004 to 2007 and 2011 to 2017), highlighting the year 2011 (15.62\%). The MMI was also applied in studies that described streams, rivers, reservoirs, estuaries, and lakes. Among the sampled environments, streams were describe in the most number of articles $(53.12 \%)$ and, consequently, a greater distribution of temporal occurrence. In contrast, lakes were described in only one study and, therefore, were not considered in rarefaction and relative frequency analyses.

Regarding the geographic distribution of the studies, the highest concentration was observed in the Southeast region (59.38\%), mainly in the Parana and East Atlantic Basins (Figure 1). Until year 2017, two basins (Tocantins and Uruguay) have not been the subject of research for the application of MMIs, and there still exists a shortage of studies in the Amazon Basin, with only two publications registered.

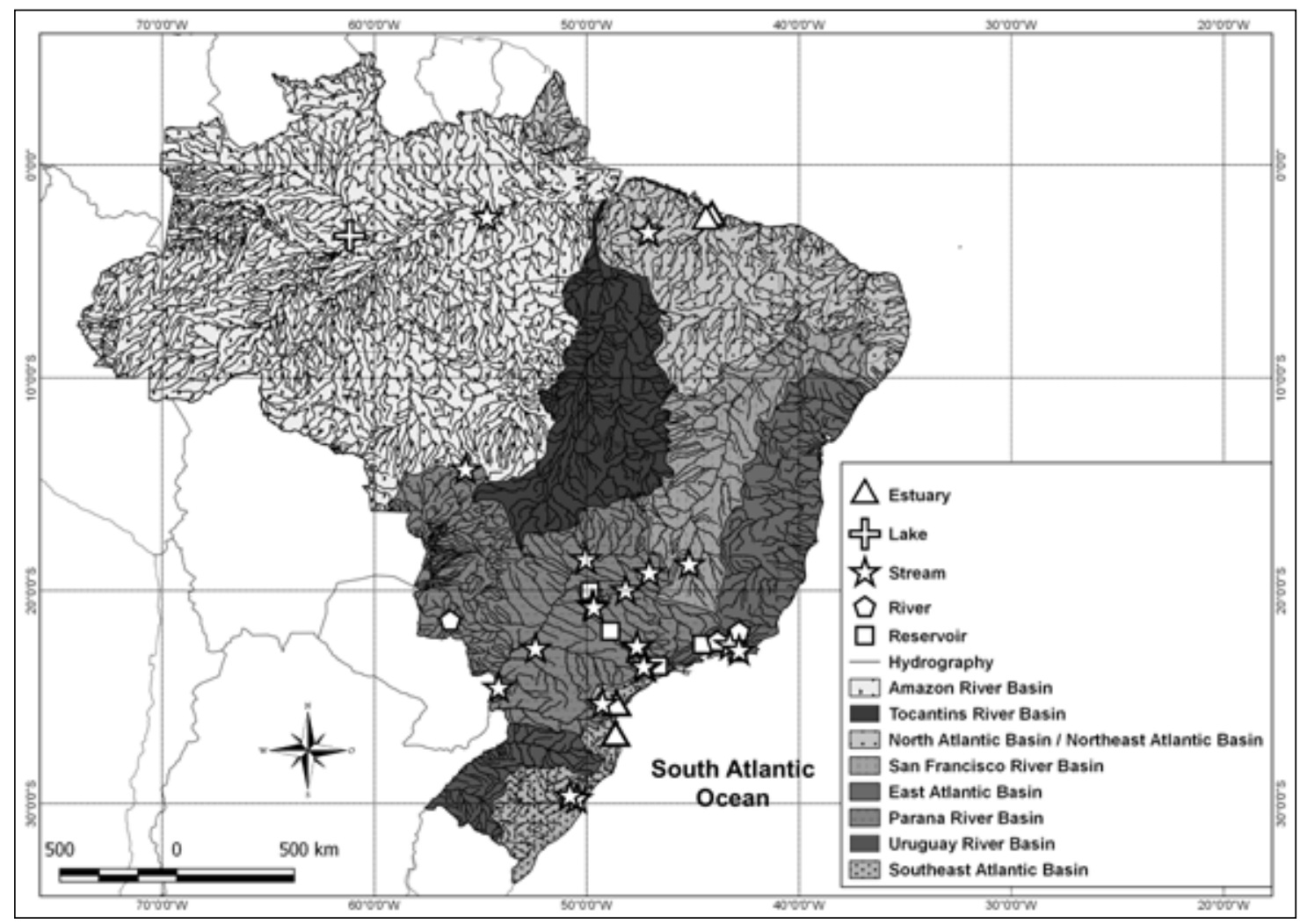

Figure 1 - Geographic distribution of the studies that used the Index of Biotic Integrity with fishes in Brazil, from 1998 to 2017, and an indication of the respective basins. 
In all, 103 metrics were recorded in the studies that were evaluated. We grouped the studies according to similar characteristics for 38 of the metrics (Supplementary 2). We observed that the most frequent factors used to calculate the index were related to the trophic guilds, considering the proportion in abundance or weight of omnivores $(7.33 \%)$ and carnivorous or piscivorous (6.96\%) fish, followed by metrics related to tolerance (5.86\%), the presence of Siluriformes (5.49\%), and the use of ecological descriptors as indexes of species diversity and dominance (5.49\%). Among the metrics mentioned above, it is noted that the proportion of abundance or weight of carnivorous or piscivorous fish was used in all environments.

The number and homogeneity of the metrics adopted in each environment were represented by the rarefaction analysis. It was possible to verify a gradual increase in number of metrics used over the years, especially in streams, due to the large number of metrics used in the MMI calculation. Only the river environment suggested asymptote of the increment curve of new metrics (Figure 2), which implies a low probability of an increase in new metrics that represent the biotic conditions in river environments.

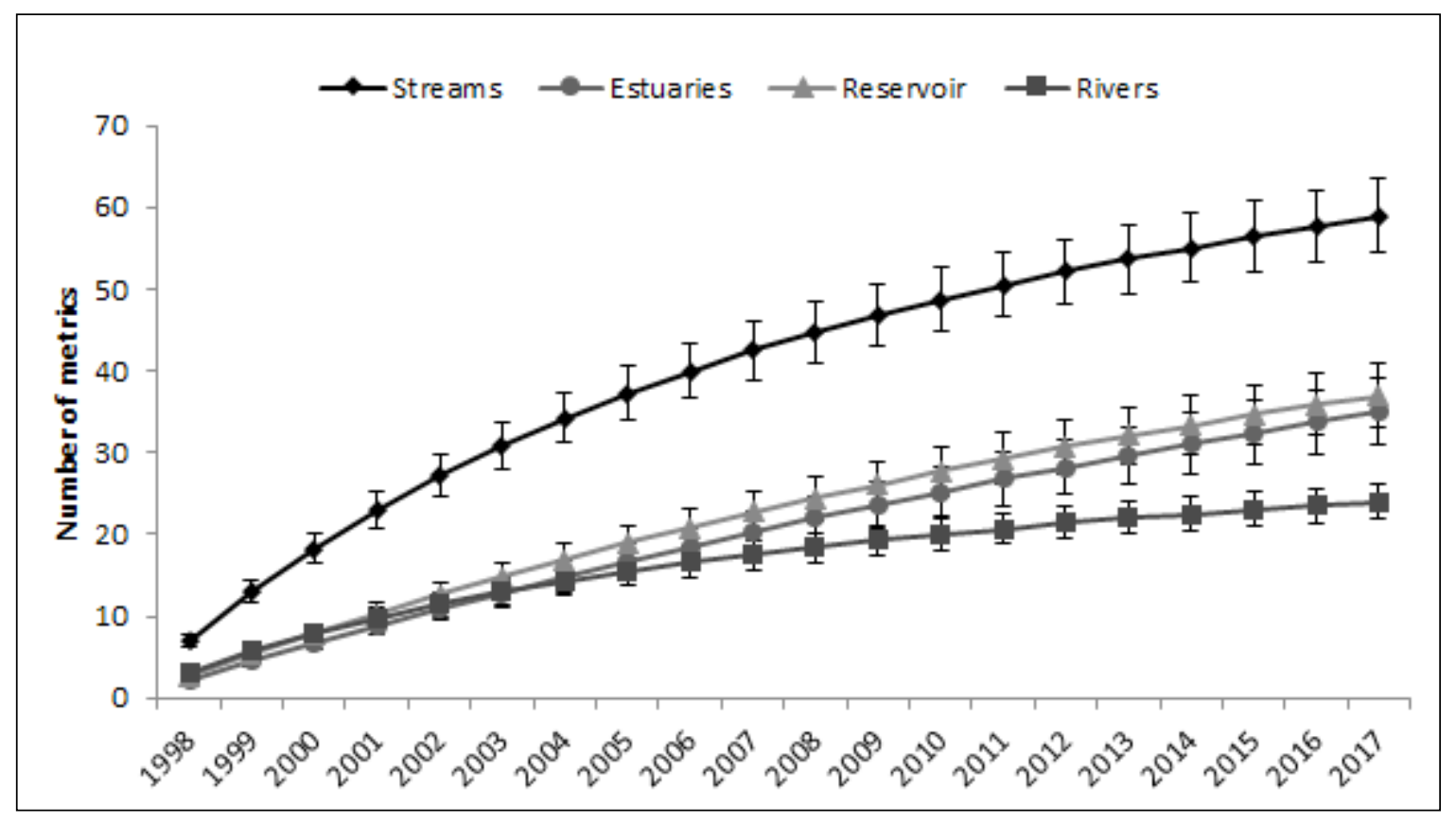

Figure 2 - Rarefaction curves showing metrics used in the calculation of MMIs in Brazil by environment and year. Horizontal lines represent the rarefaction curve, and vertical lines represent the standard deviation.

It was evident that in terms of the metrics used in the MMI calculation in the different environments that were evaluated, there were significant differences (PERMANOVA, $F=1.855, p=0.0001)$; between streams and rivers $(p=0.0002)$, reservoirs $(\mathrm{p}=0.0101)$, and estuaries $(\mathrm{p}=0.0060)$; and between estuaries and rivers $(\mathrm{p}=0.0142)$.

Regarding the relative frequency of the metrics per environment, it is notable the use of specific characteristics, especially in streams, emphasizing the proportion of omnivorous and carnivorous species, tolerance, and use of ecological descriptors. Estuaries present unique metrics related to the number of migratory and resident species (Figure 3), as well as a high occurrence of low-frequency metrics.

According to the similarity analysis (SIMPER), the distinction between environments was linked to a high proportion of the use of some metrics, such as number of Characiformes and Siluriformes species in rivers and richness of species in estuaries (Table 1). Streams, however, were segregated from the other environments due to the diversity of metrics used in the evaluation of the biotic condition in these environments. 


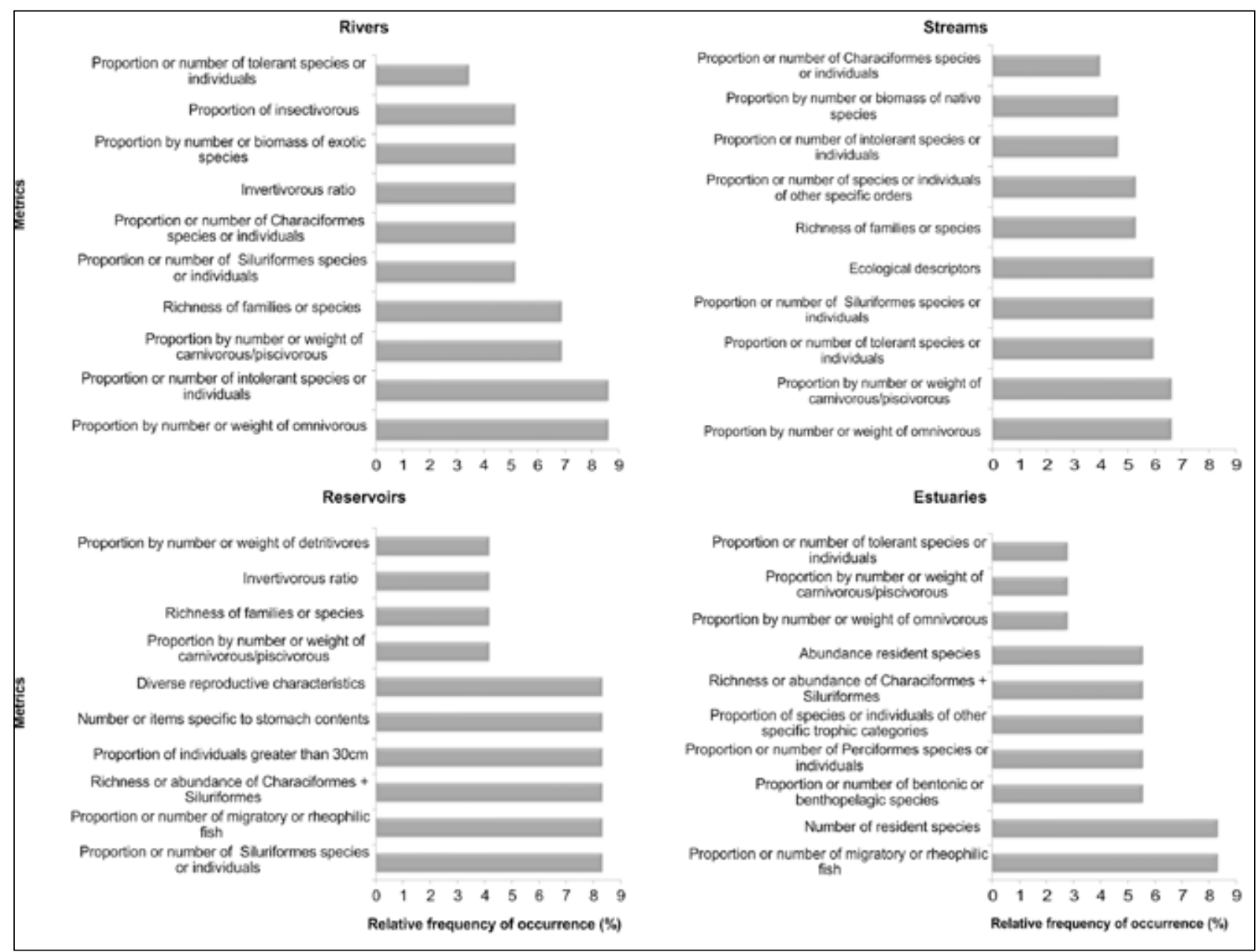

Figure 3 - Frequency of the relative occurrence of the ten principal metrics used in different environments for the calculation of MMI in Brazil (articles published between 1998 and 2017).

Table 1 - SIMPER analyses values of the metrics related to the fish fauna used in the calculation of the MMI in Brazil (from 1998 to 2017).

\begin{tabular}{|c|c|c|c|c|c|c|}
\hline $\begin{array}{l}\text { Pairs A x } \\
\text { B }\end{array}$ & $\begin{array}{c}\text { General } \\
\text { mean of } \\
\text { dissimilarity }\end{array}$ & $\begin{array}{l}\text { Higher-influenced metrics } \\
\qquad(>\mathbf{5 0} \%)\end{array}$ & $\begin{array}{c}\text { Contribution } \\
(\%)\end{array}$ & $\begin{array}{c}\text { Cumulative } \\
\text { contribution } \\
(\%)\end{array}$ & $\begin{array}{c}\text { Average } \\
\text { abundance } \\
\text { A }\end{array}$ & $\begin{array}{c}\text { Average } \\
\text { abundance } \\
\text { B }\end{array}$ \\
\hline \multirow{7}{*}{$\begin{array}{l}\text { Estuaries } \\
\text { (A) vs } \\
\text { Rivers (B) }\end{array}$} & \multirow{7}{*}{65.43} & $\begin{array}{c}\text { Proportion or number of } \\
\text { Characiformes species or } \\
\text { individuals }\end{array}$ & 6.50 & 6.50 & 0.00 & 1.00 \\
\hline & & $\begin{array}{c}\text { Proportion by number of } \\
\text { detritivorous }\end{array}$ & 5.38 & 11.87 & 0.75 & 0.00 \\
\hline & & $\begin{array}{c}\text { Proportion or number of very } \\
\text { tolerant species }\end{array}$ & 4.73 & 16.61 & 0.75 & 0.17 \\
\hline & & Number of species (richness) & 4.50 & 21.11 & 1.00 & 0.33 \\
\hline & & Abundance of native species & 4.50 & 25.61 & 0.00 & 0.67 \\
\hline & & $\begin{array}{l}\text { Number of individuals } \\
\text { (abundance) }\end{array}$ & 4.17 & 29.78 & 0.75 & 0.17 \\
\hline & & $\begin{array}{c}\text { Proportion or number of } \\
\text { Perciformes species or } \\
\text { individuals }\end{array}$ & 4.09 & 33.87 & 0.75 & 0.33 \\
\hline
\end{tabular}


Table 1 - Continuation.

\begin{tabular}{|c|c|c|c|c|c|c|}
\hline $\begin{array}{c}\text { Pairs A x } \\
\text { B }\end{array}$ & $\begin{array}{c}\text { General } \\
\text { mean of } \\
\text { dissimilarity }\end{array}$ & $\begin{array}{l}\text { Higher-influenced metrics } \\
\qquad(>\mathbf{5 0} \%)\end{array}$ & $\begin{array}{c}\text { Contribution } \\
(\%)\end{array}$ & $\begin{array}{c}\text { Cumulative } \\
\text { contribution } \\
(\%)\end{array}$ & $\begin{array}{c}\text { Average } \\
\text { abundance } \\
\text { A }\end{array}$ & $\begin{array}{l}\text { Average } \\
\text { abundance } \\
\text { B }\end{array}$ \\
\hline & & $\begin{array}{c}\text { Presence of opportunistic } \\
\text { species }\end{array}$ & 3.47 & 37.34 & 0.50 & 0.00 \\
\hline & & Number of Clupeiformes & 3.47 & 40.81 & 0.50 & 0.00 \\
\hline & & $\begin{array}{c}\text { Proportion of } \\
\text { Cyprinodontiformes }\end{array}$ & 3.42 & 44.23 & 0.00 & 0.50 \\
\hline & & $\begin{array}{c}\text { Proportion of species with } \\
\text { anomalies/pathologies }\end{array}$ & 3.40 & 47.63 & 0.50 & 0.17 \\
\hline \multirow{12}{*}{$\begin{array}{c}\text { Streams } \\
\text { (A) vs } \\
\text { Rivers (B) }\end{array}$} & \multirow{12}{*}{80.80} & $\begin{array}{c}\text { Number of Siluriformes } \\
\text { species }\end{array}$ & 5.93 & 5.93 & 0.18 & 1.00 \\
\hline & & $\begin{array}{c}\text { Proportion or number of } \\
\text { Characiformes species or } \\
\text { individuals }\end{array}$ & 5.71 & 11.63 & 0.18 & 1.00 \\
\hline & & Proportion of Carnivorous & 5.17 & 16.80 & 0.18 & 0.83 \\
\hline & & $\begin{array}{c}\text { Presence or number of } \\
\text { intolerant species }\end{array}$ & 4.96 & 21.76 & 0.24 & 0.83 \\
\hline & & Abundance of native species & 4.52 & 26.28 & 0.18 & 0.67 \\
\hline & & $\begin{array}{c}\text { Proportion by number of } \\
\text { omnivorous }\end{array}$ & 4.10 & 30.37 & 0.41 & 1.00 \\
\hline & & $\begin{array}{c}\text { Proportion of } \\
\text { Cyprinodontiformes }\end{array}$ & 3.73 & 34.11 & 0.06 & 0.50 \\
\hline & & Invertivorous ratio & 3.46 & 37.57 & 0.35 & 0.50 \\
\hline & & Number of species (Richness) & 3.23 & 40.80 & 0.41 & 0.33 \\
\hline & & $\begin{array}{c}\text { Proportion or number of } \\
\text { benthic species }\end{array}$ & 3.04 & 43.84 & 0.47 & 0.00 \\
\hline & & $\begin{array}{l}\text { Proportion or number of } \\
\text { dominant species }\end{array}$ & 2.76 & 46.60 & 0.06 & 0.33 \\
\hline & & $\begin{array}{l}\text { Presence or number of exotic } \\
\text { species }\end{array}$ & 2.60 & 49.20 & 0.12 & 0.33 \\
\hline $\begin{array}{l}\text { Streams } \\
\text { (A) vs }\end{array}$ & 83.27 & $\begin{array}{c}\text { Proportion or number of } \\
\text { Perciformes species or } \\
\text { individuals }\end{array}$ & 4.75 & 4.75 & 0.00 & 0.75 \\
\hline \multirow[t]{4}{*}{$\begin{array}{c}\text { Estuaries } \\
\text { (B) }\end{array}$} & & $\begin{array}{l}\text { Number of Siluriformes } \\
\text { species }\end{array}$ & 4.15 & 8.90 & 0.18 & 0.75 \\
\hline & & Proportion of Carnivorous & 4.15 & 13.06 & 0.18 & 0.75 \\
\hline & & $\begin{array}{c}\text { Proportion by number of } \\
\text { detritivorous }\end{array}$ & 4.13 & 17.18 & 0.18 & 0.75 \\
\hline & & $\begin{array}{c}\text { Proportion or number of very } \\
\text { tolerant species }\end{array}$ & 4.00 & 21.18 & 0.24 & 0.75 \\
\hline \multirow[t]{3}{*}{$\begin{array}{c}\text { Pairs A x } \\
\text { B }\end{array}$} & $\begin{array}{c}\text { General } \\
\text { mean of } \\
\text { dissimilarity }\end{array}$ & $\begin{array}{l}\text { Higher-influenced metrics } \\
\qquad(>\mathbf{5 0} \%)\end{array}$ & $\begin{array}{c}\text { Contribution } \\
(\%)\end{array}$ & $\begin{array}{c}\text { Cumulation } \\
\text { of } \\
\text { contribution } \\
(\%)\end{array}$ & $\begin{array}{c}\text { Average } \\
\text { abundance } \\
\text { A }\end{array}$ & $\begin{array}{c}\text { Average } \\
\text { abundance } \\
\text { B }\end{array}$ \\
\hline & & $\begin{array}{c}\text { Number of individuals } \\
\text { (abundance) }\end{array}$ & 3.52 & 28.66 & 0.24 & 0.75 \\
\hline & & Number of species (richness) & 3.40 & 32.06 & 0.41 & 1.00 \\
\hline
\end{tabular}


Table 1 - Continuation...

\begin{tabular}{|c|c|c|c|c|c|c|}
\hline $\begin{array}{c}\text { Pairs A x } \\
\text { B }\end{array}$ & $\begin{array}{c}\text { General } \\
\text { mean of } \\
\text { dissimilarity }\end{array}$ & $\begin{array}{l}\text { Higher-influenced metrics } \\
\qquad(>\mathbf{5 0} \%)\end{array}$ & $\begin{array}{c}\text { Contribution } \\
(\%)\end{array}$ & $\begin{array}{c}\text { Cumulative } \\
\text { contribution } \\
(\%)\end{array}$ & $\begin{array}{c}\text { Average } \\
\text { abundance } \\
\text { A }\end{array}$ & $\begin{array}{c}\text { Average } \\
\text { abundance } \\
\text { B }\end{array}$ \\
\hline \multirow{6}{*}{$\begin{array}{c}\text { Streams } \\
\text { (A) vs } \\
\text { Estuaries } \\
\text { (B) }\end{array}$} & \multirow{6}{*}{83.27} & $\begin{array}{c}\text { Proportion by number of } \\
\text { omnivorous }\end{array}$ & 3.16 & 35.22 & 0.41 & 0.75 \\
\hline & & Number of Clupeiformes & 3.05 & 38.27 & 0.00 & 0.50 \\
\hline & & $\begin{array}{c}\text { Proportion of species with } \\
\text { anomalies/pathologies }\end{array}$ & 3.04 & 41.31 & 0.06 & 0.50 \\
\hline & & $\begin{array}{c}\text { Presence of opportunistic } \\
\text { species }\end{array}$ & 3.02 & 44.32 & 0.06 & 0.50 \\
\hline & & $\begin{array}{c}\text { Number of demersal + pelagic } \\
\text { species }\end{array}$ & 2.64 & 46.96 & 0.00 & 0.50 \\
\hline & & $\begin{array}{l}\text { Proportion or number of } \\
\text { benthic species }\end{array}$ & 2.49 & 49.45 & 0.47 & 0.00 \\
\hline \multirow{12}{*}{$\begin{array}{c}\text { Streams } \\
\text { (A) vs } \\
\text { Reservoirs } \\
\text { (B) }\end{array}$} & \multirow{12}{*}{87.82} & $\begin{array}{c}\text { Number of Siluriformes } \\
\text { species }\end{array}$ & 3.66 & 3.66 & 0.18 & 0.75 \\
\hline & & Proportion of carnivorous & 3.37 & 7.03 & 0.18 & 0.75 \\
\hline & & $\begin{array}{l}\text { Proportion or number of very } \\
\text { tolerant species }\end{array}$ & 3.27 & 10.29 & 0.24 & 0.75 \\
\hline & & $\begin{array}{c}\text { Proportion by weight of } \\
\text { omnivorous }\end{array}$ & 3.02 & 13.32 & 0.00 & 0.50 \\
\hline & & $\begin{array}{l}\text { Proportion of individuals } \\
\text { greater than } 30 \mathrm{~cm}\end{array}$ & 2.91 & 16.23 & 0.00 & 0.50 \\
\hline & & $\begin{array}{l}\text { Proportion or number of } \\
\text { Perciformes species or } \\
\text { individuals }\end{array}$ & 2.91 & 19.14 & 0.00 & 0.50 \\
\hline & & $\begin{array}{c}\text { Proportion by number of } \\
\text { omnivorous }\end{array}$ & 2.87 & 22.01 & 0.41 & 0.75 \\
\hline & & $\begin{array}{l}\text { Number of individuals } \\
\text { (abundance) }\end{array}$ & 2.85 & 24.86 & 0.24 & 0.50 \\
\hline & & $\begin{array}{l}\text { Presence or number of exotic } \\
\text { species }\end{array}$ & 2.56 & 27.42 & 0.12 & 0.50 \\
\hline & & Abundance of native species & 2.55 & 29.98 & 0.18 & 0.50 \\
\hline & & $\begin{array}{l}\text { Proportion or number of } \\
\text { dominant species }\end{array}$ & 2.53 & 32.50 & 0.06 & 0.50 \\
\hline & & $\begin{array}{c}\text { Proportion or number of } \\
\text { Characiformes species or } \\
\text { individuals }\end{array}$ & 2.51 & 35.01 & 0.18 & 0.50 \\
\hline & & $\begin{array}{l}\text { Proportion of species with } \\
\text { anomalies/pathologies }\end{array}$ & 2.51 & 37.52 & 0.06 & 0.50 \\
\hline & & Number of species (richness) & 2.41 & 39.93 & 0.41 & 0.25 \\
\hline & & $\begin{array}{l}\text { Proportion of species } \\
\text { representing } 90 \% \text { individuals }\end{array}$ & 2.39 & 42.32 & 0.00 & 0.50 \\
\hline & & $\begin{array}{l}\text { Proportion or number of } \\
\text { benthic species }\end{array}$ & 2.37 & 44.69 & 0.47 & 0.00 \\
\hline & & Invertivorous ratio & 1.97 & 46.67 & 0.35 & 0.00 \\
\hline & & $\begin{array}{l}\text { Presence or number of } \\
\text { intolerant species }\end{array}$ & 1.83 & 48.50 & 0.24 & 0.25 \\
\hline
\end{tabular}




\section{Discussion}

The low application of MMIs using the ichthyofauna in Brazil, the absence of temporal and spatial patterns, and the high number of metrics reflect peculiarities of the scientific knowledge about the fish fauna in the Brazilian territory, mainly in relation to streams. The basis of the MMI framework is compounded by the lack of basic knowledge about the biology of many species, policies, and infrastructure for inventories and for the implementation of long-term monitoring. In addition, the enormous territorial dimensions and high climatic, physiographic, and biological variability contribute to this scenario of low similarity and standardization of attributes in the MMI calculations among the studies evaluated here. However, recent studies have used more robust selection tools and designs to minimize these biases (CARVALHO et al., 2017; CHEN et al., 2014), demonstrating the ability of MMIs to detect effects of anthropogenic components on aquatic ecosystems (PETESSE et al., 2016).

The publication of scientific research related to studies involving fish fauna in Brazil greatly increased after 2000 (DIAS et al., 2016), possibly as a result of the country's economic stabilization after the 1994 monetary reform (METTENHEIM, 2004), as well as recognition of the importance of preserving group diversity. These factors reflect the temporal fluctuations observed in the present study and that are commonly present in the development of scientific guidelines, still linked to different factors, such as innovation, acceptance and alternative approaches. Thus, it is probable that the application of the MMI will not be discarded by the national scientific community because this tool does not have a consolidated design for or against its use.

The scenario of application of studies mentioned above cannot be generalized in relation to the geographical distribution of research. The highest concentration of publications related to the evaluation of MMIs was found verified in the center and south of the region, and these patterns follow the patterns already reported by Azevedo et al. (2010) for fish-related studies that used other approaches. The focus on MMIs is related to the greater number of freshwater research groups established in these regions (DIAS et al., 2016), with important contributions from post-graduate programs (NABOUT et al., 2015). In addition, the application of MMIs seems to be related to the objectives of the work of each researcher and associated with their ideology. This hypothesis gains support in the finding of a low incidence of studies focused on MMIs in the Amazon Basin, for example, despite the high regional scientific productivity that is fomented by the presence of the Instituto Nacional de Pesquisas da Amazônia (INPA) (AZEVEDO et al., 2010). In addition, the use of the MMI is less attractive in this basin as a result of protective legal actions, such as the Protected Areas and Conservation Units (VERÍSSIMO et al., 2011), and the fact that it is a basin that is proportionally lower in its anthropic footprint (ABELL et al., 2008).

The criteria for the definition of sampling sites in Brazil, apparently considered the potentiality of response of the local fish community in function of the adopted metrics, that is, the representation of the attributes in the environmental quality assessment. In this sense, Roset et al. (2007) highlighted some critical factors that are part of the MMI proposal, such as location, seasonal variations, and accuracy and sensibility of the metrics. Although these factors are often neglected, recent adaptations of the index have considered the importance of these assumptions in assessing biotic integrity (for example, PETESSE et al., 2014; CARVALHO et al., 2017).

The predominance of adaptations of MMIs for streams may be related to the specificities of these environments, as they are easily accessible for researchers with small collection infrastructures and they have low water volumes, which facilitates sampling (GALVEZ et al., 2009; CASATTI, 2010). In addition, during recent decades, there has been a greater call for the identification of impacts of anthropic actions in these environments (for example, urban and agricultural expansion and introduction of non-native species). Additionally, it seeks to obtain information from little-known processes before they are lost (BÖHLKE et al., 1978; AZEVEDO et al., 2010; DIAS et al., 2016), especially in relation to endemic fauna (CASTRO, 1999; CASATTI, 2010). Moreover, the influence of impact factors from surroundings is more pronounced than in larger places, such as in rivers and lakes.

We identified a lower frequency of studies in environments with large geographic dimensions (for example, marine environments), marked seasonal variations (for example, floodplains, lakes, and estuaries), and a lack of methodological adaptations in those with greater depth (JARAMILLO-VILLA; CARAMASCHI, 2008). In this sense, it is possible that new metrics should be added with the evolution of IBI studies; this is especially true in estuaries, given their amplitude and heterogeneity (PÉREZ-DOMÍNGUES et al., 2012).

Simplifications about the increasing fragmentation of rivers as a result of the implantation of reservoirs are widely discussed and are based on other approaches (PELICICE et al., 2015; AGOSTINHO et al., 2016). This fact may explain the low representativeness and adoption of new metrics in this environment. The absence of pristine environments of similar proportions and the absence of studies prior to the implementation of most of these projects make it difficult to make comparisons about the application of MMI.

In general, the metrics used in MMI calculations seek to evaluate specific characteristics of different aquatic ecosystems. The high quantity and non-standardization of the attributes make it difficult to compare studies, and we observed redundancy in terms of the functional characteristics. However, there were some aspects of the fish community that were common among environments and that were frequently used, which suggests a high sensitivity to environmental changes. Trophic-related metrics were highlighted because the reduction of specific guilds and the increase of trophic generalists indicated impacts to the biotic integrity that have already been consolidated in the literature (FAUSCH et al., 1990). 
The proportion of tolerant individuals was another frequent metric, which indicates the ability to establish and maintain a given population given a specific set of environmental conditions (BOZZETI; SCHULZ, 2004). In order to better understand this concept, it was necessary to consider the abundance of each species captured and its physiological and functional characteristics, which are directly related to each other and to an individual's survival (TERESA et al., 2015; AGOSTINHO et al., 2016). The high response capacity of these attributes justifies its adoption for the determination of biotic integrity.

The high heterogeneity and the quantity of metrics used in studies of streams reflect the high magnitude of the Brazilian water network, as well as the specificities of these environments, such as richness and endemism (ABELL et al., 2008; NOGUEIRA et al., 2010; MIRANDA, 2012), which explains the number of different attributes what were used in comparison to the other environments. However, for rivers, despite the high structural diversity (SCHIEMER, 2000), the imminent temporal asymptote of the number of metrics evaluated is due to abiotic factors and equivalent biotic interactions in different basins (MINATTIFERREIRA; BEAUMORD, 2006), which allows for the standardization of the characteristics used in the index calculation.

In some cases, the aspects considered in different aquatic ecosystems were standardized. This was especially relevant to studies in reservoirs, which had predictable metrics (FERREIRA et al., 2015) as a result of known anthropic disturbances (CROOK et al., 2015; GRACEY; VERONES, 2016) and previous knowledge of the ecology of these environments. On the other hand, estuarine environments presented greater variation between regions with regard to the ecology of local species and the conditions considered as minimally impacted, being necessary adaptations according to intrinsic characteristics to the indicator group (VIANA et al., 2012; FISCH et al., 2016).

In general, the great difficulty in applying the MMI is the selection of factors that, on the one hand, effectively characterize the state of a specific ecological system and, on the other, can be compared and generalized on more global scales. From this perspective, the use of MMI in the Brazilian territory presents additional difficulties when compared to other countries (DALE; BEYELER, 2001). In Europe and in the United States of America, biomonitoring is a primary action for the determination of the ecological status of water bodies, helping to interpret the current conditions of the environment in a way that would indicate whether conservation or restoration were needed (BIRK et al., 2012). However, Brazilian environmental regulations neglect the diagnosis of ecological components in the classification of environmental quality.

\section{Conclusions}

We identified a low occurrence of studies that apply MMI in the Brazilian fish community and a lack of standardized metrics. Moreover, we determined from this survey that there are several gaps in terms of the application of the MMI in Brazil, highlighting regions (north and northeast) and environments (marine, estuaries, and lakes) that have only been explored in limited ways. In addition, we also highlight the absence of standardized metrics and a neglect of metrics related to functional characteristics. We expect these findings to motivate public managers and the scientific community to join efforts in long-term researches, particularly in terms of the neglected scales, regions, and environments highlighted in this study. We believe that the critical state of fish fauna and Brazilian aquatic ecosystems support the need for the urgent development of tools for the prognosis, conservation, and restoration of these environments.

\section{Acknowledgment}

Grateful to the colleagues of the Post Graduate Program in Conservation and Natural Resources Management, Campus Cascavel-PR, for assistance in information collection.

\section{References}

ABELL R, THIEME ML, REVENGA C, BRYER M, KOTTELAT M, BOGUTSKAYA N, et al. Freshwater ecoregions of the world: a new map of biogeographic units for freshwater biodiversity conservation. BioScience. 2008;58(5):403-414.

AGOSTINHO AA, GOMEZ LC, SANTOS NCL, ORTEGA JCG, PELICICE FM. Fish assemblages in Neotropical reservoirs: colonization patterns, impacts and management. Fisheries Research. 2016;173:26-36.

ARAÚJO FG. Adaptação do índice de integridade biótica usando a comunidade de peixes para o rio Paraíba do Sul. Revista Brasileira de Biologia. 1998;58:547-558. 
AZEVEDO PG, MESQUITA FO, YOUNG RJ. Fishing for gaps in science: a bibliographic analysis of Brazilian freshwater ichthyology from 1986 to 2005. Journal of Fish Biology. 2010;76(9):2177-2193.

BASTOS LP, ABILHOA V. A utilização do índice de integridade biótica para avaliação da qualidade de água: um estudo de caso para riachos urbanos da bacia hidrográfica do rio Belém, Curitiba, Paraná. Revista Estudos de Biologia. 2004;26(55):33-44.

BIRK S, BONNE W, BORJA A, BRUCET S, COURRAT A, POIKANE S, et al. Three hundred ways to assess Europe's surface waters: an almost complete overview of biological methods to implement the Water Framework Directive. Ecological Indicators. 2012;18:31-41.

BLOCKSOM KA. A performance comparison of metric scoring methods for a multimetric index for Mid-Atlantic Highlands streams. Environmental Management. 2003;31(5):670-682.

BÖHLKE JE, WEITZMAN SH, MENEZES NA. Estado atual da sistemática dos peixes de água doce da América do Sul. Acta Amazônica. 1978;8:657-677.

BOZZETTI M, SCHULZ UH. An index of biotic integrity based on fish assemblages for subtropical streams in southern Brazil. Hydrobiologia. 2004;529(1):133-144.

BRASIL. Decreto no 24.643, de 10 de julho de 1934. Decreta o Código de Águas. Diário Oficial da União, Brasília, DF, jul. 1934. Seção 1, p.14738.

BRASIL. Lei no 9.433, de 8 de janeiro de 1997. Institui a Política Nacional de Recursos Hídricos e cria o Sistema Nacional de Gerenciamento de Recursos Hídricos. Diário Oficial da União, Brasília, DF, jan. 1997. Seção 1, p. 470.

CARVALHO DR, LEAL CG, JUNQUEIRA NT, CASTRO MA, FAGUNDES DC, ALVEZ CBM, et al. A fish-based multimetric index for Brazilian savanna streams. Ecological Indicators. 2017;77:386-396.

CASATTI L. Alterações no Código Florestal Brasileiro: impactos potenciais sobre a ictiofauna. Biota Neotropica. 2010;10(4):31-34.

CASTRO RMC. Evolução da ictiofauna de riachos sul-americanos: padrões gerais e possíveis processos causais. In: CARAMASCHI EP, MAZZONI R, PERES-NETO PR. (eds.). Ecologia de Peixes de Riachos: Estado Atual e Perspectivas. Oecologia Brasiliensis. VI, Rio de Janeiro. 1999:139-155.

CHEN K, HUGHES RM, XU S, ZHANG J, CAI D, WANG B. Evaluating performance of macroinvertebrate-based adjusted and unadjusted multi-metric indices (MMI) using multi-season and multi-year samples. Ecological Indicators. 2014;36:142151.

CROOK DA, LOWE WH, ALLENDORF FW, ERÖS T, FINN DS, GILLANDERS BM, et al. Human effects on ecological connectivity in aquatic ecosystems: integrating scientific approaches to support management and mitigation. Science of the Total Environment. 2015;534:52-64.

DALE VH, BEYELER SC. Challenges in the development and use of ecological indicators. Ecological Indicators. 2001;1(1):3-10.

DIAS MS, ZUANON J, COUTO TBA, CARVALHO M, CARVALHO LN, ESPÍRITO-SANTO HMV, et al. Trends in studies of Brazilian stream fish assemblages. Natureza \& Conservação. 2016;14(2):106-111.

EUROPEAN COMMISSION. Directive 2000/60/EC. Establishing a framework for community action in the field of water policy. European Commission PE-CONS 3639/1/100 Rev. 1, Luxembourg, 2000.

FAUSCH KD, LYONS J, KARR JR, ANGERMEIER PL. Fish communities as indicators of environmental degradation. American Fisheries Society Symposium. 1990;8:123-144.

FERREIRA FC, SOUZA UP, PETRERE JRM. Presence of riparian vegetation increases biotic condition of fish assemblages in two Brazilian reservoirs. Acta Limnologica Brasiliensia. 2015;27(3):289-300.

FISCH F, BRANCO JO, MENEZES JT. Ictiofauna como indicador da integridade biótica de um ambiente de estuário. Acta Biológica Colombiana. 2016;21(1):27-38.

FLORES-LOPES F, MALABARBA LL. R. Revisão de alguns aspectos da assembleia de peixes utilizados em programas de monitoramento ambiental. Vittalle - Revista de Ciências da Saúde. 2007;19(1):45-58. 
GALVES W, SHIBATTA AO, JEREP FC. Estudos sobre diversidade de peixes da bacia do alto rio Paraná: uma revisão histórica. Semina: Ciências Biológicas e da Saúde. 2009;30(2):141-154.

GRACEY EO, VERONES F. Impacts from hydropower production on biodiversity in an LCA framework-review and recommendations. The International Journal of Life Cycle Assessment. 2016;21(3):412-428.

HAMMER Ø, HARPER DAT, RYAN PD. PAST: paleontological statistics software package for education and data analysis. Palaeontologia Electronica. 2001;4:9.

HERING D, FELD CK, MOOG O, OFENBÖCK T. Cook book for the development of a Multimetric Index for biological condition of aquatic ecosystems: experiences from the European AQEM and STAR projects and related initiatives. Hydrobiologia. 2006;566(1):311-324.

HERLIHY AT, LARSEN DP, PAULSEN SG, URQUHART NS, ROSENBAUM BJ. Designing a spatially balanced, randomized site selection process for regional stream surveys: the EMAP Mid-Atlantic pilot study. Environmental Monitoring and Assessment. 2000;63(1):95-113.

JARAMILLO-VILLA U, CARAMASCHI EP. Índices De Integridade Biótica Usando Peixes De Água Doce: Uso Nas Regiões Tropical e Subtropical. Oecologia Brasiliensis. 2008;12(3):442-462.

JENNINGS MJ, FORE LS, KARR JR. Biological monitoring of fish assemblages in Tennessee Valley reservoirs. Regulated Rivers: Research \& Management. 1995;11:263-274.

KARR JR. Assessment of biotic integrity using fish communities. Fisheries. 1981;6(6):21-27.

KARR JR, DUDLEY DR. Ecological perspective on water quality goals. Environmental Management. 1981;5(1):55-68.

LYONS J, HERNÁNDEZ AG, PARDO ED, GALERA ES, NAVA MM, LÓPEZ RP. Development of a preliminary index of biotic integrity (IBI) based on fish assemblages to assess ecosystem condition in the lakes of central Mexico. Hydrobiologia. 2000;418(1):57-72.

MARTINEZ-HARO M, BEIRAS R, BELLAS J, CAPELA R, COELHO JP, LOPES I, et al. A review on the ecological quality status assessment in aquatic systems using community based indicators and ecotoxicological tools: what might be the added value of their combination? Ecological Indicators. 2015;48:8-16.

METTENHEIM KV. From the economics of politics to the politics of monetary policy. University of Oxford Centre for Brazilian Studies Working Paper. 2004:54-74.

MINATTI-FERREIRA DD, BEAUMORD AC. Adequação de um protocolo de avaliação rápida de integridade ambiental para ecossistemas de rios e riachos: aspectos físicos. Revista Saúde e Ambiente. 2006;7(1):39-47.

MIRANDA JC. Ameaças aos peixes de riachos da Mata Atlântica. Natureza on line. 2012;10(3):136-139.

NABOUT JC, CARNEIRO FM, BORGES PP, MACHADO KB, HUSZAR VLM. Brazilian scientific production on phytoplankton studies: national determinants and international comparisons. Brazilian Journal of Biology. 2015;75(1):216223.

NOGUEIRA C, BUCKUP PA, MENEZES NA, OYAKAWA OT, KASECKER TP, NETO MBR, et al. Restricted-range fishes and the conservation of Brazilian freshwaters. PLoS ONE. 2010;5(6):e11390. doi:10.1371/journal.pone.0011390.

PELICICE FM, POMPEU SP, AGOSTINHO AA. Large reservoirs as ecological barriers to downstream movements of Neotropical migratory fish. Fish and Fisheries. 2015;16(4):697-715.

PÉREZ-DOMÍNGUEZ R, MACIA S, COURRAT A, LEPAGE M, BORJA A, URIARTE A, et al. Current developments on fish-based indices to assess ecological-quality status of estuaries and lagoons. Ecological Indicators. 2012;23:34-45.

PETESSE ML, PETRERE Jr M, AGOSTINHO AA. Defining a fish bio-assessment tool to monitoring the biological condition of a cascade reservoirs system in tropical area. Ecological Engineering. 2014;69:139-150.

PETESSE ML, SIQUEIRA-SOUZA FK, FREITAS CEC, PETRERE Jr M. Selection of reference lakes and adaptation of a fish multimetric index of biotic integrity to six amazon floodplain lakes. Ecological Engineering. 2016;97:535-544.

QGIS DEVELOPMENT TEAM. QGIS Geographic Information System. Open Source Geospatial Foundation Project. 2016. 
ROSET NG, GRENOUILLET G, GOFFAUX D, PONT D, KESTEMONT P. A review of existing fish assemblage indicators and methodologies. Fisheries Management and Ecology. 2007;14(6):393-405.

RUARO R, GUBIANI EA. A scientometric assessment of 30 years of the Index of Biotic Integrity in aquatic ecosystems: applications and main flaws. Ecological Indicators. 2013;29:105-110.

SCHIEMER F. Fish as indicators for the assessment of the ecological integrity of large rivers. Hydrobiologia. 2000;422:271278.

TERESA FB, CASATTI L, CIANCIARUSO MV. Functional differentiation between fish assemblages from forested and deforested streams. Neotropical Ichthyology. 2015;13(2):361-370.

TUNDISI JG, TUNDISI TM. Limnologia. 1ª Ed. São Paulo: Oficina de Textos; 2008.

USEPA (UNITED STATES ENVIRONMENTAL PROTECTION AGENCY). Summary of biological assessment programs and biocriteria development for states, tribes, territories, and interstate commissions: streams and wadeable rivers. EPA822-R-02-048. U.S. Environmental Protection Agency, Washington, DC, 2002.

VERÍSSIMO A, ROLLA A, VEDOVETO M, FUTADA SM. (Org.) Áreas protegidas na Amazônia brasileira: avanços e desafios. Belém, Imazon. São Paulo: Instituto Socioambiental; 2011.

VIANA AP, FRÉDOU FL, FRÉDOU T. Measuring the ecological integrity of an industrial district in the Amazon estuary, Brazil. Marine Pollution Bulletin. 2012;64(3):489-499.

WHITTIER TR, STODDARD JL, LARSEN DP, HERLIHY AT. Selecting reference sites for stream biological assessments: best professional judgment or objective criteria. Journal of the North American Benthological Society. 2007;26(2):349-360.

Douglas Ticiani
$\begin{gathered}\text { Universidade Estadual do Oeste do Paraná - UNIOESTE, Cascavel-PR, Brasil. } \\ \text { Email: ticiani.douglas@gmail.com }\end{gathered}$
Programa de Pós-Graduação em Conservação e Manejo de Recursos Naturais,
Mestrando em Conservação e Manejo de Recursos Naturais
Raquel Fernanda Bogoni
Universidade Estadual do Oeste do Paraná - UNIOESTE, Cascavel-PR, Brasil.
Email: raquelbogoni@hotmail.com
Ana Cristina Algeri Eichelberger
Universidade Estadual do Oeste do Paraná - UNIOESTE, Cascavel-PR, Brasil.
Email: anacristinaalgeri@gmail.com
Amanda Frigo Berlatto
Universidade Estadual do Oeste do Paraná - UNIOESTE, Cascavel-PR, Brasil.
Email: a.fberlatto@gmail.com
Gabriela Medeiros
Eniversidade Estadual do Oeste do Paraná - UNIOESTE, Cascavel-PR, Brasil.
Email: gabsmedeiros@gmail.com
Rosilene Luciana Delariva
Universidade Estadual do Oeste do Paraná - UNIOESTE, Cascavel-PR, Brasil.
Centro de Ciências Biológicas e da Saúde
Email: rosilene.delariva@unioeste.br

